\title{
Erratum to: The effect of character contextual diversity on eye movements in Chinese sentence reading
}

\author{
Qingrong Chen ${ }^{1}$ - Guoxia Zhao ${ }^{1}$ - Xin Huang ${ }^{1} \cdot$ Yiming Yang $^{2}$ • \\ Michael K. Tanenhaus ${ }^{1,3}$
}

Published online: 9 June 2017

(C) Psychonomic Society, Inc. 2017

\section{Erratum to: Psychon Bull Rev}

\section{DOI: $10.3758 / \mathbf{s} 13423-017-1278-8$}

This paper was published with some of the Chinese characters appearing incorrectly in the online version. The original article has been corrected.

The online version of the original article can be found at http://dx.doi.org/ 10.3758/s13423-017-1278-8

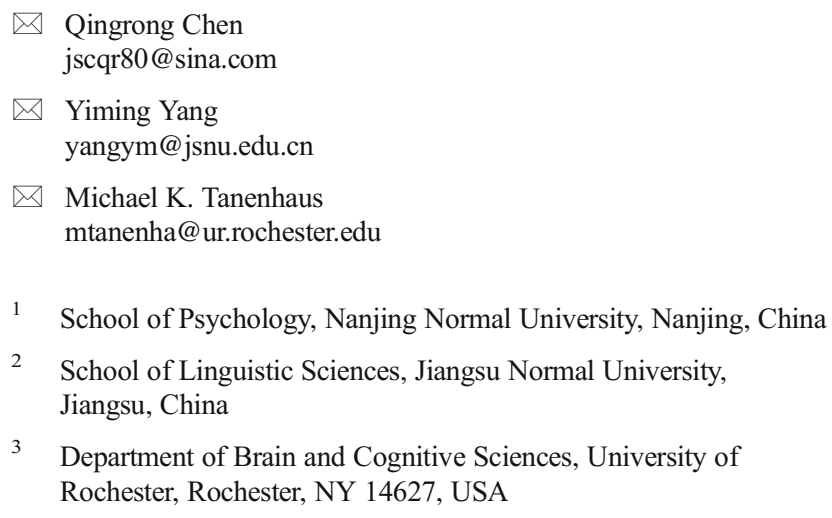

3 Department of Brain and Cognitive Sciences, University of Rochester, Rochester, NY 14627, USA 
Table 1 Experimental conditions and exemplar sentences in Experiment 1.

\begin{tabular}{llr}
\hline Condition & Example & Plausibility \\
\hline Control & $\begin{array}{l}\text { 妈妈把佐料放到了柜子里。 } \\
\text { Mother put the condiment in the cupboard. } \\
\text { LCF }\end{array}$ & $\begin{array}{l}\text { 妈妈把组 带放到了柜子里。 } \\
\text { Mother put the bandage in the cupboard. }\end{array}$ \\
HCD & $\begin{array}{l}\text { 妈妈把抹 布放到了柜子里。 } \\
\text { Mother put the duster in the cupboard. }\end{array}$ & $5.20(0.60)$ \\
\hline
\end{tabular}

Note: English glosses are literal translations. The target characters are in bold. English translations of all test sentences for Experiment 1 and Experiment 2 are available by request from the first author (jscqr80@sina.com).

Table 6 Experimental conditions and exemplar sentences in Experiment 2.

\begin{tabular}{|c|c|c|c|}
\hline Condition & Example & Difficulty & Plausibility \\
\hline Control & $\begin{array}{l}\text { 拉里说街道两旁回响的凯 歌无法换回战友的生命。 } \\
\text { Lali said that victorious song that was reverberating on both sides of the street did not let comrade-in-arms live } \\
\text { again. }\end{array}$ & $\begin{array}{l}1.43 \\
\quad(0.05)\end{array}$ & $5.50(0.16)$ \\
\hline LCF & $\begin{array}{l}\text { 我认为过去发生的纠 纷可能会明显影响这次合作。 } \\
\text { I think the disputes that have occurred in the past may significantly affect this cooperation. }\end{array}$ & $\begin{array}{r}1.44 \\
(0.06)\end{array}$ & $5.43(0.17)$ \\
\hline HCD & $\begin{array}{l}\text { 妹妹认为这种畅销的坚 果非常符合年轻人的口味。 } \\
\text { My sister thinks that the best-selling nuts are very suitable for young people's tastes. }\end{array}$ & $\begin{array}{l}1.44 \\
(0.05)\end{array}$ & $5.24(0.16)$ \\
\hline
\end{tabular}

Note: English glosses are literal translations. The target characters are in bold. 